Cooper, K. E. (1968). In Recent Advances in Medicine, ed. D. N. Baron, N. Compston, and A. M. Dawson, 15th edn., p. 343. London, Churchill. Davies, D. M., Millar, E. J., and Miller, I. A. (1967). Lancet, 1, 1036. Duguid, H., Simpson, R. G., and Stowers, J. M. (1961). Lancet, 2, 1213. Emslic-Smith, D. (1958). Lancet, 2, 492.

Fogel, R. L., Epstein, J. A., Stopak, J. H., and Kupperman, H. S. (1962). New York State fournal of Medicine, $62,1159$.

Gilson, W. E. (1959). New England fournal of Medicine, 260, 1027.

Gooding, G. T. (1969). British Fournal of Clinical Practice, 23, 40.

Griffiths, P. D. (1965). Fournal of Clinical Pathology, 18, 660.

Hardwick, R. G. (1962). British Medical fournal, 1, 147.

Hockaday, T. D. R., and Fell, R. H. (1969). British Fournal of Hospital Medicine, 2, 1083.

Hubble, D. (1955). Lancet, 1, 1.

Hurwitz, L. J., McCormick, D., and Allen, I. V. (1970). Lancet, 1, 67

Jellinek, E. H. (1960). D. M. thesis, Oxford: cited by Jellinek, E. H. (1964) Lancet, 2, 529.

Lambert, E. H., Underdahl, L. O., Beckett, S., and Mederos, L. O. (1951). fournal of Clinical Endocrinology and Metabolism, 11, 1186.

Maclean, D., Griffiths, P. D., and Emslie-Smith, D. (1968). Lancet, 2, 1266. Mathews, J. A. (1966). Postgraduate Medical fournal, 42, 495.
Mathews, J. A. (1967). Postgraduate Medical fournal, 43, 662.

Miles, D. W., and Surveyor, I. (1965). British Medical fournal, 1, 158.

Moulopoulos, S. D., Koutras, D. A., and Kralios, A. C. (1964). Lancet, 1, 85.

Nordqvist, P., Dhuner, K.-G., Stenberg, K., and Orndahl, G. (1960). Acta Medica Scandinavica, 166, 189.

Nuki, G., and Bayliss, R. I. S. (1968). Postgraduate Medical Fournal, 44, 97. Ord, W. M. (1884). British Medical fournal, 2, 205.

Petajan, J. H., and Watts, N. (1962). American fournal of Physical Medicine, $41,240$.

Rees, J. R. (1958). Lancet, 1, 556

Rosin, A. J., and Exton-Smith, A. N. (1964). British Medical fournal, 1, 16.

Sherman, L., Goldberg, M., and Larson, F. C. (1963). Lancet, 1, 243.

Sprunt, J. G., Maclean, D., and Browning, M. C. K. (1970). Lancet, 1, 324

Sprunt, J. G., Maclean, D., and Browning,

Taylor, G. (1964). Practitioner, 193, 761. Technicon method N-56: Estimation of Protein Bound Iodine. New York,
(n) Chauncey.

Waal-Manning, H. J. (1969). Clinical Pharmacology and Therapeutics, 10, 199.

Zingg, W. (1967). Canadian Medical Association fournal, 96, 214.

\title{
Interaction between Levodopa and Methyldopa
}

\author{
F. B. GIBBERD, ELIZABETH SMALL
}

British Medical fournal, 1973, 2, 90-91

\section{Summary}

The interaction between methyldopa and levodopa was studied in 18 patients with Parkinsonism. Together they produced a fall in blood pressure in doses which when given alone had no effect or only a slight hypotensive effect. Severe hypotension never occurred. It is reasonable to give methyldopa to hypertensive patients on levodopa but the regimen should be initiated in hospital.

\section{Introduction}

Since the introduction of levodopa for the treatment of patients with Parkinsonism a variety of interactions between levodopa and other drugs have been reported (Hunter et al., 1970).

Theoretically, an interaction between levodopa and methyldopa could be envisaged since methyldopa can cause Parkinsonism by inhibiting decarboxylase, thus preventing the conversion of dopa to dopamine.

Although levodopa has been reported to cause postural hypotension (Barbeau, 1969; Calne, 1969; Calne, 1970; Duvoisin, 1970; McDowell and Lee, 1970) the hypotension is not related to the dose. In the past, it has been thought inadvisable to give methyldopa and levodopa together. However, many patients with Parkinsonism have hypertension and are effectively controlled on methyldopa. Fermaglich and O'Doherty (1971) reporting on patients with Parkinsonism who received both drugs found that Parkinsonism was improved by adding methyldopa to levodopa. The average dose of levodopa was reduced from $3.244 \mathrm{~g}$ to $0.96 \mathrm{~g}$ when methlydopa was added. However, careful assessment of the blood pressure was not made.

In this study the interaction between the two drugs on the blood pressure is investigated.

Westminster Hospital Group, London SW1P 2AP

F. B. GIBBERD, M.B., F.R.C.P., Consultant Physician

ELIZABETH SMALI, M.B., M.R.C.P., Senior Registrar in Physical Medicine

\section{Method}

Eighteen inpatients with Parkinsonism were investigated as follows. While not receiving treatment, lying and standing blood pressure measurements were recorded at 6 a.m., 11 a.m., 1 p.m., and 3 p.m. The effect of a single dose of 250 $\mathrm{mg}$ methyldopa was assessed by administering the drug at 6 a.m. and measuring lying and standing blood pressures at 6 a.m., 11 a.m., 1 p.m., and 3 p.m. The patients were then started on treatment with levodopa until two weeks later, with the patient on a mean dose or $1.5 \pm 0.5 \mathrm{~g}$ levodopa a further $250 \mathrm{mg}$ of methyldopa was administered and lying and standing pressure again monitored at 6 a.m., 11 p.m., 1 p.m.; and 3 p.m.

Three of the patients were also given methyldopa $250 \mathrm{mg}$ twice a day for one day while on a dose of 1.75-2.5 g levodopa.

\section{Results}

Results of the standing blood pressure are shown in the table. Four comparisons were made. First between a control period and methyldopa, second between a control and

Results of Standing Blood Pressure Measurements in the Study Groups

\begin{tabular}{|c|c|c|c|c|}
\hline & & & \multicolumn{2}{|c|}{ Standing Blood Pressure ( $\mathrm{mm} \mathbf{~ H g}$ ) } \\
\hline & & & Systolic & Diastolic \\
\hline $\begin{array}{l}\text { Mean control } \ldots \\
\text { Mean methyldopa } \\
\text { Difference of mean } \\
\text { No. of readings .. }\end{array}$ & $\begin{array}{l}\cdots \\
\cdots \\
\therefore\end{array}$ & $\begin{array}{l}\ldots \\
\cdots \\
\cdots\end{array}$ & $\begin{array}{c}136 \cdot 1 \\
134 \cdot 7 \\
1 \cdot 4 \\
18\end{array}$ & $\begin{array}{l}99 \cdot 0 \\
77 \cdot 2 \\
12 \cdot 8 \\
18\end{array}$ \\
\hline Significance & $\ldots$ & $\ldots$ & $P>0.50$ & $0.01<P<0.02$ \\
\hline $\begin{array}{l}\text { Mean control } \quad \ldots \\
\text { Mean levodopa } \quad \ldots \\
\text { Difference of mean } \\
\text { No. of readings } \quad .\end{array}$ & $\begin{array}{l}. \\
\because \\
\therefore \\
\end{array}$ & $\begin{array}{l}\ldots \\
\cdots \\
\cdots\end{array}$ & $\begin{array}{c}136 \cdot 1 \\
135 \cdot 6 \\
0.5 \\
18\end{array}$ & $\begin{array}{l}99 \cdot 6 \\
80 \cdot 6 \\
10 \\
18\end{array}$ \\
\hline Significance & $\ldots$ & $\ldots$ & $P>0.05$ & $0.1<P<0.5$ \\
\hline $\begin{array}{l}\text { Mean methyldopa } \\
\text { Mean methyldopa and le } \\
\text { Difference of mean } \\
\text { No. of readings .. }\end{array}$ & $\begin{array}{l}\text { evodopa } \\
\ldots \\
\therefore\end{array}$ & & $\begin{array}{c}134 \cdot 2 \\
120 \cdot 3 \\
13 \cdot 9 \\
44\end{array}$ & $\begin{array}{c}77 \cdot 8 \\
71 \cdot 1 \\
6 \cdot 7 \\
44\end{array}$ \\
\hline Significance & .. & $\ldots$ & $P<0.01$ & $<0.01$ \\
\hline $\begin{array}{l}\text { Mean levodopa } \\
\text { Mean levodopa and met } \\
\text { Difference of mean } \\
\text { No. of readings ... }\end{array}$ & $\begin{array}{l}\text { hyldopa } \\
\ldots \\
\ldots\end{array}$ & $\begin{array}{l}\cdots \\
\cdots\end{array}$ & $\begin{array}{c}135 \cdot 3 \\
123 \cdot 3 \\
12 \\
18\end{array}$ & $\begin{array}{l}80 \cdot 0 \\
74 \cdot 7 \\
5 \cdot 3 \\
18\end{array}$ \\
\hline Significance & $\ldots$ & 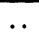 & $0.02<P<0.05$ & $0.1<P<0.5$ \\
\hline
\end{tabular}


levodopa, third between methyldopa and methyldopa with levodopa and fourth between levodopa and levodopa with methyldopa. These four comparisons were not made simultaneously.

There was no effect on lying blood pressure from these drugs either singly or in combination. Methyldopa alone produced a slight fall in standing diastolic blood pressure, levodopa and methyldopa together produced a fall in standing systolic and standing diastolic blood pressure. The three patients on the higher dose of levodopa (mean dose $2 \mathrm{~g}$ ) who received $500 \mathrm{mg}$ methyldopa showed the same blood pressure changes as before.

\section{Discussion}

Our trial did not confirm the findings of Calne (1970) who found that with levodopa alone a fall occurred in the mean systolic pressure of $19.3 \mathrm{~mm} \mathrm{Hg}$ when standing. However, we did not use maximally tolerated doses of the drug.

The hypotensive effect of these two drugs in combination is likely to be that of potentiation rather than synergism but too few patients were studied to be certain of this. In Fermaglich and O'Doherty's (1971) investigation no change in the blood pressure was noted but special studies of the blood pressure would be needed in order to show slight change. Hunter et al. (1970) found that for a hypertensive patient on guanthidine the dose of this drug had to be substantially reduced if the patient was put on levodopa. The results show that methyldopa and levodopa together lowered the blood pressure in doses which, given singly, did not affect it significantly.

Parkinsonism was unaffected by the administration of methyldopa, but our patients were given the drug for only a few days. There are reports, however, of Parkinsonism induced by methyldopa (Peaston, 1964; Vaidya et al., 1970) in people who had no Parkinsonism symptoms before they took methyldopa. In another report by Groden (1963) Parkinsonism returned to a patient when he was given methyldopa, his previous Parkinsonism having occurred when on reserpine. Methyldopa crosses the blood brain barrier in animals and therefore theoretically it could be interacting with levodopa in the extrapyramidal system.

Levodopa like methyldopa may produce a state of autoimmunity with a positive Coombs test (Cotzias, 1969), but no cases of haemolytic anaemia have been reported. In our series haemolytic anaemia did not occur, although a Coombs test was not done regularly.

It is reasonable to consider giving methyldopa to hypertensive patients on levodopa. This should be attempted only in a hospital, where the blood pressure can be carefully monitored and the dosage of the drug slowly increased.

\section{References}

Barbeau, A. (1969). Science, 165, 291.

Calne, D. B. (1969). British fournal of Pharmacology and Chemotherapy, $37,57$.

Calne, D. B. (1970). British Medical fournal, 1, 474

Cotzias, G. C. (1969). Fournal of the American Medical Association, 207, 1353. Duvoisin, R. C. (1970). British Medical Fournal, 3, 47.

Fermaglich, J., and O'Doherty, D. S. (1971). Neurology, 21, 408.

Groden, B. M. (1963). British Medical fournal, 1, 1001.

Hunter, K. R., Stern, G. M., and Lawrence, D. R. (1970). Lancet, 2, 1283. McDowell, F. H., and Lee, J. E. (1970). Annals of Internal Medicine, 72, 751. Peaston, M. J. T. (1964). British Medical fournal, 2, 168.

Vaidya, R. A., Vaidya, A. B., Van Woert, M. H., and Kass, N. G. (1970). Metabolism: Clinical and Experimental, 19, 1069.

\section{MEDICAL MEMORANDA}

\section{Clostridium welchii Infection: An Unusual Case}

\section{J. ENGESET, J. MACINTYRE, G. SMITH, G. WELCH}

British Medical fournal, 1973, 2, 92-93

Clostridium welchii infection is a recognized complication of open injuries sustained in road accidents. The infection usually originates in an inadequately excised wound containing ischaemic tissue. We report a case of gas gangrene occurring in the apparently normal leg of a road traffic accident victim with a compound fracture of the opposite leg.

\section{Case History}

A 24-year-old man was involved in a road accident in which he sustained a compound fracture of the shaft of the left tibia and fibula, and minor abrasions over the right greater trochanter and

Department of Surgery, University of Aberdeen, Aberdeen AB9 2ZD

J. ENGESET. CH.M., F.R.C.S., Lecturer in Surgery

J. MACINTYRE, F.R.c.S., Surgical Registrar

G. SMITH, M.D., CH.M,, Regius Professor of Surgery

Department of Orthopaedics, Raigmore Hospital, Inverness

G. WELCH, M.B., F.R.C.s., Consultant Orthopaedic Surgeon the left anterior chest wall. He was admitted to hospital and the wound in the left leg was excised and sutured under general anaesthesia. The limb was then immobilized in plaster. Next day he was well, but complained of a little pain in his right thigh. The pain gradually became more severe. Two days after injury the right thigh was noticeably swollen and tender. A radiograph showed a small quantity of gas in the muscle planes. Within the next couple of hours the thigh rapidly increased in size and crepitus became detectable. A diagnosis of gas gangrene was made. Under general anaesthetic the whole right lower limb was carefully examined for evidence of a wound and none found. There was trivial bruising over the right greater trochanter and a number of injection sites were noted in the right buttock where tetanus vaccine $0.5 \mathrm{ml}$ had been injected shortly after the injury.

An incision was then made from the anterior superior iliac spine to the lateral border of the patella. A large quantity of gas escaped both when the superficial fascia and when the deep fascia were opened. The rectus femoris muscle was found to be necrotic from end to end. It was excised completely. The other muscles of the anterior compartment of the thigh were examined and appeared healthy, normally coloured, and contractile despite the presence of gas in the tissue planes. The wound was left open.

C. welchii was identified on the smear and later cultured anaerobically as a pure growth of type A. No other organism was grown. Despite a history of an allergy to penicillin he was given two megaunits intramuscularly, blood transfusion was started, and he was given sodium bicarbonate intravenously $(250 \mathrm{ml}$ of $4.2 \%) . \mathrm{He}$ was promptly transferred to the hyperbaric oxygen unit at the department of surgery, University of Aberdeen.

There the thigh wound was treated by continuous hydrogen peroxide irrigation (hydrogen peroxide solution B.P. " 20 volume"). He was given $2,000 \mathrm{ml}$ of blood during the first 24 hours and he received 5 megaunits of penicillin intravenously 6-hourly together with $1 \mathrm{~g}$ probenecid daily. Hyperbaric oxygen therapy at three 